\title{
Protective effect of carboxymethylated chitosan on hydrogen peroxide-induced apoptosis in nucleus pulposus cells
}

\author{
BIN HE, HAIYING TAO, SHIQING LIU and AILIN WEI \\ Department of Orthopaedics, Renmin Hospital of Wuhan University, Wuhan, Hubei 430060, P.R. China
}

Received February 1, 2014; Accepted September 29, 2014

DOI: $10.3892 / \mathrm{mmr} .2014 .2942$

\begin{abstract}
Although the etiology of intervertebral disc degeneration is poorly understood, one approach to prevent this process may be to inhibit apoptosis. In the current study, the anti-apoptotic effects of carboxymethylated chitosan (CMCS) in nucleus pulposus (NP) cells were investigated with the aim to enhance disc cell survival. Rat NP cells were isolated and cultured in vitro, and hydrogen peroxide $\left(\mathrm{H}_{2} \mathrm{O}_{2}\right)$ was used to build the NP cell apoptosis model. Cell viability was assessed with a cell counting kit- 8 assay. The ratio of apoptotic cells was surveyed by annexin V-fluorescein isothiocyanate (FITC) and propidium iodide (PI) double staining analysis, and the morphology was observed by Hoechst 33342 staining. The mitochondrial membrane potential of NP cells was evaluated by rhodamine 123 fluorescence staining. Reverse transcription (RT)-quantitative polymerase chain reaction (qPCR) was performed to measure mRNA levels of inducible nitric oxide synthase (iNOS), caspase-3, B-cell lymphoma (Bcl)-2, type II collagen and aggrecan. Western blot analysis was performed to detect protein levels of iNOS and Bcl-2. The annexin V-FITC/PI and Hoechst 33342 staining results indicated that CMCS was able to prevent NP cells from apoptosis in a dose-dependent manner. Rhodamine 123 staining clarified that CMCS reduced the impairment of the mitochondrial membrane potential in $\mathrm{H}_{2} \mathrm{O}_{2}$-treated NP cells. Reduced caspase- 3 and increased Bcl-2 activity were detected in CMCS-treated NP cells by RT-qPCR and western blot analysis. CMCS also promoted the proliferation and secretion of type II collagen and aggrecan in $\mathrm{H}_{2} \mathrm{O}_{2}$-treated NP cells. CMCS was indicated to be effective in preventing apoptotic cell death in vitro, demonstrating the potential advantages of this therapeutic approach in regulating disc degeneration.
\end{abstract}

Correspondence to: Dr Bin He, Department of Orthopaedics, Renmin Hospital of Wuhan University, 238 Jiefang Road, Wuchang, Wuhan, Hubei 430060, P.R. China

E-mail: hebin@whu.edu.cn

Key words: apoptosis, intervertebral disc degeneration, nucleus pulposus cells, carboxymethylated chitosan

\section{Introduction}

Degeneration of the intervertebral disc (IVD) is a primary cause of lower back pain (LBP) and is a prerequisite for the occurrence of IVD hernia (1), which has a high social and economic cost. Regardless, the pathological mechanism of IVD degeneration remains to be fully defined. It is commonly accepted that IVD degeneration is influenced by numerous factors, including age, genetics and mechanical stimuli, of which the latter is the most important (2-6). Although mechanical stress is established to be an important modulator of degeneration, the underlying molecular mechanism of nucleus pulposus (NP) cells in the degeneration of the IVDs remains to be fully elucidated.

The IVD is composed of two conspicuous and interdependent anatomical structures: The surrounding annulus fibrosus (AF) and the central gelatinous NP. IVD cells, particularly NP cells, are crucial to maintain the integrity of the IVD, which occurs through producing type II collagen, aggrecan and other components involved in extracellular matrix (ECM) metabolism. A reduced NP cell population and loss of ECM are central features in the aging and degeneration of IVDs. Previous evidence has suggested that the NP may be associated with aging and the initiation of IVD degeneration (7-9). One study, focusing on the cellular mechanobiology of IVD, suggested that NP cells possess distinct characteristics necessary for IVD homeostasis (10). Although the precise molecular mechanism of IVD degeneration remains unclear, previous studies have suggested that the apoptosis or programmed cell death in NP cells may be one of the key factors $(11,12)$.

Apoptosis is an active mode of cell death that is observed in healthy cells and tumor cells, in physiological and pathological situations, and is distinct from passive cell death (necrosis) (13). The signaling events leading to apoptosis can be divided into two distinct pathways, either involving the mitochondria or death receptors. In the mitochondrial pathway, death signals lead to changes in mitochondrial membrane permeability, and the subsequent release of pro-apoptotic factors, such as cytochrome $c$ from the mitochondria. Once in the cytoplasm, cytochrome $c$ catalyzes the oligomerization of apoptotic protease activating factor-1 (Apaf-1) (14). This promotes the activation of procaspase- 9 , which then initiates a caspase cascade involving the downstream executioner, procaspase-3, which in turn activates a DNase, termed caspase-activated DNase $(15,16)$. In the death receptor pathway, apoptosis is 
triggered by cell surface death receptors, including Fas and the tumor necrosis factor (TNF) receptor, which contain death domains. These death domains recruit adaptors and induce the activation of initiator caspase-8, followed by cleavage of downstream effector caspase and various substrates. Park et al (17) established that NP cells participate in the intrinsic pathway and subsequently undergo apoptotic cell death through mitochondrial involvement. The cellular commitment to apoptosis is regulated by the $\mathrm{B}$-cell lymphoma $(\mathrm{Bcl})-2$ family of proteins, which consists of apoptosis agonists (Bax, Bak and Bad) and antagonists (Bcl-2 and Bcl-xl). The balance between pro-apoptotic proteins, such as Bax, and anti-apoptotic proteins, such as Bcl-2, is considered to be a crucial factor in the regulation of apoptosis. Bax and $\mathrm{Bcl}-2$ are mitochondrial proteins, and have been demonstrated to be associated with the regulation of mitochondrial membrane permeability. Bax exerts its pro-apoptotic activity by translocating from the cytoplasm to the mitochondria, and inducing cytochrome $c$ release from isolated mitochondria. However, Bcl-2 exerts its anti-apoptotic activity, at least in part, by inhibiting the translocation of Bax to the mitochondria.

Carboxymethylated chitosan (CMCS) is a soluble derivative of chitosan and it possesses numerous desirable physiochemical and biological features. It has been indicated previously that CMCS can significantly suppress the degeneration of cartilage in osteoarthritis and protect chondrocytes from interleukin-1 $\beta$-induced catabolism and apoptosis $(18,19)$. It has been previously observed that CMCS can stimulate proliferation and the secretion of NGF in cultured Schwann cells (SCs) by activation of the mitogen-activated protein kinase/extracellular signal-regulated kinase, phosphatidylinositide 3-kinase/Akt and Wnt/ $\beta$-catenin signaling cascades $(20,21)$. The protection of NP cells from apoptosis possesses great potential for the treatment of IVD degeneration, and the present study aims to determine whether CMCS serves a similar function in NP cells as in chondrocytes and SCs.

The aim of the current study was to investigate whether CMCS is effective in preventing hydrogen peroxide $\left(\mathrm{H}_{2} \mathrm{O}_{2}\right)$-induced apoptotic cell death, and to discuss the potential advantages of this approach in providing a therapeutic approach to the regulation of IVD degeneration.

\section{Materials and methods}

Animals and reagents. 24 healthy male Sprague-Dawley (SD) rats with an average body weight (BW) of $362 \pm 35 \mathrm{~g}$ were selected as NP cell donors (obtained from the Center of Experimental Animals of Wuhan University, Wuhan, China). Dulbecco's modified Eagle's medium/Ham's F-12 (DMEM/F-12) was obtained from Gibco Life Technologies (Carlsbad, CA, USA) and fetal bovine serum (FBS) was obtained from HyClone (Logan, UT, USA). Carboxymethylated chitosan (CMCS, purity $>99 \%$ ) was supplied by the Institute of Chemistry and Environmental Science of Wuhan University. A cell counting kit-8 (CCK-8) was purchased from Dojindo Molecular Technologies, Inc. (Kumamoto, Japan). Primers were provided by Invitrogen Life Technologies (Carlsbad, CA, USA). Rabbit polyclonal anti-Bcl-2 (\#2876) and rabbit monoclonal anti- $\beta$-actin (13E5; \#4970) antibodies were obtained from Cell Signaling Technology, Inc. (Beverly, MA, USA). The anti-inducible nitric oxide synthase rabbit polyclonal (iNOS; sc-651) antibody was from Santa Cruz Biotechnology, Inc. (Dallas, TX, USA). Rhodamine 123 (Rho123) and Hoechst 33342 were obtained from Sigma-Aldrich (St. Louis, MO, USA). Phosphate-buffered saline (PBS, x10, ST476) and SDS-PAGE Gel Kit (P0012A), were obtained from the Beyotime Institute of Biotechnology (Haimen, China) and were of the highest purity commercially available.

Cell isolation and culture. 5 SD rats (aged 10-12 weeks, weighing $362 \pm 35 \mathrm{~g}$ ) were enrolled in the present study. Rat NP cells were isolated using a previously described explant culture method (22). Briefly, rats were euthanized with an overdose of intravenous pentobarbital $(100 \mathrm{mg} / \mathrm{kg}$ body weight; Shanghai Biorui Biological Technological Co., Ltd., Shanghai, China), and the lumbar IVDs were resected from the spinal column. The gel-like NP tissue was separated from the AF using a dissection microscope (Five-Lake Medical Devices Co., Ltd., Wuhan, China) under aseptic conditions. The gelatinous NP tissues obtained from each animal were cut into small pieces $\left(<1 \mathrm{~mm}^{3}\right)$ immediately, then digested with $0.1 \%$ type-2 collagenase (Sigma-Aldrich) in DMEM/F-12 at $37^{\circ} \mathrm{C}$ in a KYC-100C gyratory shaker from Shanghai Fuma Laboratory Instrument Company (Shanghai, China) at $110 \mathrm{rpm}$. After $4 \mathrm{~h}$, the suspension was filtered through a $70-\mu \mathrm{m}$ mesh. The filtered cells were washed with DMEM/F-12 and then seeded into $25 \mathrm{~cm}^{2}$ culture flasks. The cells were incubated in DMEM/F-12 with $10 \%$ FBS and a penicillin-streptomycin solution (SV30010; HyClone; $100 \mathrm{U} / \mathrm{ml}$ streptomycin and $100 \mathrm{U} / \mathrm{ml}$ penicillin) in a $5 \% \mathrm{CO}_{2}$ incubator. The medium was refreshed every 3 days. The NP cells were chondrocyte-like cells, identified by type II collagen and aggrecan immunohistostaining.

Establishment of apoptotic models of NP cells. To establish the apoptotic model of cultured NP cells, $\mathrm{H}_{2} \mathrm{O}_{2}$ (Wuhan Boster Biological Technology Company, Wuhan, China). was used as described previously (23). Briefly, NP cells (cell density of $1 \times 10^{6} / \mathrm{ml}$ ) were cultured overnight at $37^{\circ} \mathrm{C}$ in the culture medium as described above. Different concentrations of $\mathrm{H}_{2} \mathrm{O}_{2}$ $(100,200$ and $300 \mu \mathrm{M})$ were used to induce the damage to NP cells. NP cells were examined at 6, 12 and 24 h subsequent to the addition of $\mathrm{H}_{2} \mathrm{O}_{2}$. To determine the effects of CMCS on $\mathrm{H}_{2} \mathrm{O}_{2}$-induced apoptosis in NP cells, cell cultures were treated with $\mathrm{H}_{2} \mathrm{O}_{2}$ for $6 \mathrm{~h}$ and then the culture medium was replaced immediately by fresh medium with $\mathrm{CMCS}$. The concentrations of CMCS were 50, 100 and $200 \mu \mathrm{g} / \mathrm{ml}$.

Cell viability assay. Cell viability was assessed by CCK-8 assay. Cells were suspended at a final concentration of $2 \times 10^{4}$ cells/well and cultured in 96-well flatbottomed microplates with the DMEM/F-12 containing $0.1 \%$ FBS. The medium was replaced 24 h later with DMEM/F-12 containing $\mathrm{H}_{2} \mathrm{O}_{2}$, CMCS or phosphate-buffered saline (PBS; control group). For assessing the cytotoxic effect of $\mathrm{H}_{2} \mathrm{O}_{2}$ with CMCS, cells were incubated with 100, 200 and $300 \mu \mathrm{M} \mathrm{H}_{2} \mathrm{O}_{2}$ without CMCS, and $300 \mu \mathrm{M} \mathrm{H}_{2} \mathrm{O}_{2}$ with different concentrations of CMCS $(50,100$ and $200 \mu \mathrm{g} / \mathrm{ml})$ for the indicated time intervals. For quantitative analysis of the cell proliferation, $10 \mu \mathrm{l}$ CCK-8 solution was added to each 
well of a 96-well flat bottomed microplate containing $100 \mu 1$ $\mathrm{DMEM} / \mathrm{F}-12$, and the plate was incubated at $37^{\circ} \mathrm{C}$ for $1 \mathrm{~h}$ in a $5 \% \mathrm{CO}_{2}$ atmosphere. The optical density, which is proportional to cell metabolic activity, was measured at $450 \mathrm{~nm}$ using an ELx800 Absorbance Microplate Reader (BioTek Instruments, Inc., Winooski, VT, USA). Cell viability was expressed as a percentage of the number of control (untreated) cells. Viability in the control group was designated as $100 \%$. The cell viability of each group was calculated as follows: Cell viability (\% of control $)=[(\mathrm{Ae}-\mathrm{Ab}) /(\mathrm{Ac}-\mathrm{Ab})] \times 100$. Ae, $\mathrm{Ab}$ and $\mathrm{Ac}$ represent the A450 of the experimental, blank and control groups, respectively. All experiments were performed in triplicate in three independent experiments.

Annexin V-fluorescein isothiocyanate(FITC)/propidium iodide $(P I)$ staining. The level of apoptotic death in the NP cells was determined using flow cytometric analysis. Cellular apoptosis was observed by annexin V-FITC/PI double staining, performed using an Annexin V/FITC Apoptosis Detection kit I (no. 556547; BD Biosciences, Franklin Lakes, NJ, USA) according to the manufacturer's instructions. Briefly, cells were cultured at a density of $6 \times 10^{5}$ cells $/ \mathrm{ml}$ and seeded in 6-well plates. The cells were cultured in DMEM/ F-12 containing various concentrations of $\mathrm{H}_{2} \mathrm{O}_{2}(100,200$ and $300 \mu \mathrm{M}$ ) for 6,12 or $24 \mathrm{~h}$, or CMCS at various concentrations $(50,100$ and $200 \mu \mathrm{g} / \mathrm{ml})$ for $3 \mathrm{~h}$ followed by the addition of $\mathrm{H}_{2} \mathrm{O}_{2}$ for $24 \mathrm{~h}$ for the indicated time. Cells were harvested by trypsinization (Gibco-BRL, Rockville, MD, USA), then washed twice with cold PBS and centrifuged at $400 \mathrm{x}$ g. Approximately $1 \times 10^{5}-1 \times 10^{6}$ cells were then suspended in $500 \mu \mathrm{l}$ binding buffer from the apoptosis detection kit, centrifuged again at $400 \mathrm{x}$ g for $5 \mathrm{~min}$ and then the supernatant was removed. Cells were resuspended in $500 \mu \mathrm{l}$ binding buffer and transferred to a sterile flow cytometry glass tube. Annexin V-FITC (5 $\mu \mathrm{l})$ and PI $(5 \mu \mathrm{l})$ were added prior to incubation in the dark at room temperature. Cells were analyzed with a flow cytometer (BD Biosciences) at $488 \mathrm{~nm}$. The distribution of cells was analyzed using Cell Quest Pro software (version 4.01; BD Biosciences) in the BD FACSVerse ${ }^{\mathrm{TM}}$ flow cytometer (BD Biosciences) within $1 \mathrm{~h}$ of staining. Data from 10,000 cells were collected for each data file. Apoptotic cells were identified as the annexin V-FITC-positive and PI-negative cells. Finally, the number of cells in each category was expressed as a percentage of the total number of stained cells.

Nuclear staining with Hoechst 33342. Apoptotic nuclear morphology was assessed with Hoechst 33342 (Sigma-Aldrich) staining. To determine whether CMCS protects from recognized morphological features of apoptosis, such as $\mathrm{H}_{2} \mathrm{O}_{2}$-induced chromatin condensation and fragmentation, cells were cultured in 6 -well plates $\left(3.0 \times 10^{5}\right.$ cells/well) with DMEM/F-12 containing $10 \%$ FBS, then treated for $24 \mathrm{~h}$ with $300 \mu \mathrm{M} \mathrm{H}_{2} \mathrm{O}_{2}$ and $\mathrm{CMCS}$ at $37^{\circ} \mathrm{C}$ in a humidified atmosphere of $5 \% \mathrm{CO}_{2}$. Cell apoptosis was evaluated by Hoechst 33342 staining as described previously (24). Briefly, following $24 \mathrm{~h}$ culture in the DMEM/F-12 medium, the cells were stained with $10 \mu \mathrm{g} / \mathrm{ml}$ Hoechst 33342 at $37^{\circ} \mathrm{C}$ for $20 \mathrm{~min}$. The cells were washed and suspended again in PBS for morphological observation under a IX51 fluorescence microscope (Olympus
Corporation, Tokyo, Japan) with excitation at $355 \mathrm{~nm}$ and emission at $465 \mathrm{~nm}$. A minimum of 400 cells from six randomly selected fields per dish were counted, and each treatment was performed in triplicate.

Measurement of mitochondrial membrane potential ( $\Delta \Psi \mathrm{m})$. Changes in $\Delta \Psi \mathrm{m}$ were estimated by the uptake of Rho123, a cell-permeant, lipophilic, cationic, fluorescent dye that permeates easily and interacts with negative charges on the inner mitochondrial membrane at a low concentration. It accumulates in normal mitochondria, but a decline in $\Delta \Psi$ m leads to leakage of Rho123 from the mitochondria, thus the fluorescence intensity is reduced. Therefore, the effects of $\mathrm{H}_{2} \mathrm{O}_{2}$, CMCS and a combination of the two on $\Delta \Psi \mathrm{m}$ were assessed as one of the markers of mitochondrial function. Briefly, $\mathrm{H}_{2} \mathrm{O}_{2}$ or $\mathrm{H}_{2} \mathrm{O}_{2} / \mathrm{CMCS}$ treatments were performed for $24 \mathrm{~h}$. At the end of incubation, treated NP cells were incubated with Rho123 $(10 \mu \mathrm{g} / \mathrm{ml})$ at $37^{\circ} \mathrm{C}$ for $20 \mathrm{~min}$. Subsequently, they were washed twice with PBS and then observed with the excitation filter set at $488 \mathrm{~nm}$ and the emission filter at $510 \mathrm{~nm}$ under the fluorescence microscope.

Reverse transcription (RT)-quantitative polymerase chain reaction $(q P C R)$. Total RNA was extracted using TRIzol reagent (Invitrogen Life Technologies, Carlsbad, CA, USA) according to the manufacturer's protocol. The RNA samples were quantified by spectrophotometry at 260 and $280 \mathrm{~nm}$ (A260/A280 2.0; A260 = $40 \mu \mathrm{g}$ RNA/ml) by the NanoDrop (ND-8000) Spectrophotometer (Thermo Fisher Scientific, Braunschweig, Germany). RNA was then reverse-transcribed to cDNA using a Reverse Transcription-Polymerase Chain Reaction kit (Takara Biotechnology Co., Ltd., Dalian, China) according to the manufacturer's instructions. The cDNA was analyzed immediately or stored at $-20^{\circ} \mathrm{C}$. qPCR amplification was performed with an ABI Prism 7900HT Real-Time PCR system (Applied Biosystems Life Technologies, Foster City, CA, USA), and the SYBR Green I fluorescent dye method was used to quantify cDNA. PCR cycling conditions consisted of an initial denaturing step for $10 \mathrm{sec}$ at $95^{\circ} \mathrm{C}$; then 40 cycles of $5 \mathrm{sec}$ each at $95^{\circ} \mathrm{C}$; followed by $30 \mathrm{sec}$ at $60^{\circ} \mathrm{C}$. A stable and reliable standard curve was established by plotting the threshold cycle $(\mathrm{Ct})$ values. Following amplification, a melting curve analysis was performed in order to verify the authenticity of the amplified product by its specific melting temperature (Tm). GAPDH was used as the internal control. The relative levels of mRNA of the target genes were then calculated, through which the gene expression level and the trend of change were determined. The specificity of each reaction was controlled by melting curve analysis. A negative PCR control containing water in place of cDNA was prepared. The relative levels of mRNA were analyzed by the $2^{-\Delta \Delta \mathrm{Ct}}$ method. qPCR was conducted in triplicate in three independent experiments. The sequences of the primers are presented in Table I.

Western blot analysis. NP cells were treated with $\mathrm{H}_{2} \mathrm{O}_{2}$ in the presence or absence of CMCS. Samples of the cell cultures were treated with lysis buffer (P0013, Beyotime Institute of Biotechnology) containing $150 \mathrm{mM} \mathrm{NaCl}, 10 \mathrm{mM}$ Tris- $\mathrm{HCl}$, 1 mM EDTA, 1\% Triton X-100, 10\% glycerol, $1 \mathrm{mM}$ 
Table I. Primers used for RT-qPCR analysis of gene expression.

\begin{tabular}{|c|c|c|c|}
\hline Gene & Primer & Sequence & Produce size (bp) \\
\hline iNOS & $\begin{array}{l}\text { Forward } \\
\text { Reverse }\end{array}$ & $\begin{array}{l}\text { 5'-GCAGACACATACTTTATGC-3' } \\
\text { 5'-CAATGGCTGGTACATGGGCAC-3' }\end{array}$ & 445 \\
\hline $\mathrm{Bcl}-2$ & $\begin{array}{l}\text { Forward } \\
\text { Reverse }\end{array}$ & $\begin{array}{l}\text { 5'-GCGTCAACAGGGAGATGTCA-3 } \\
\text { 5'-GGTATGCACCCAGAGTGATG-3' }\end{array}$ & 225 \\
\hline Caspase-3 & $\begin{array}{l}\text { Forward } \\
\text { Reverse }\end{array}$ & $\begin{array}{l}\text { 5'-GGCCTGCTTTTTACCTCAGA-3' } \\
\text { 5'-CGTTTCCGCACAGGCTGCTT-3 }\end{array}$ & 140 \\
\hline Collagen-2 & $\begin{array}{l}\text { Forward } \\
\text { Reverse }\end{array}$ & $\begin{array}{l}\text { 5'-CCCAGAACATCACCTACCAC-3 } \\
\text { 5'-GGTACTCGATGATGGTCTTG-3 }\end{array}$ & 201 \\
\hline Aggrecan & $\begin{array}{l}\text { Forward } \\
\text { Reverse }\end{array}$ & $\begin{array}{l}\text { 5'-GATGTCCCCTGCAATTACCA-3 } \\
\text { 5'-TCTGTGCAAGTGATTCGAGG-3 }\end{array}$ & 230 \\
\hline GAPDH & $\begin{array}{l}\text { Forward } \\
\text { Reverse }\end{array}$ & $\begin{array}{l}\text { 5'-TGTCTCCTGCGACTTCAACAG-3' } \\
\text { 5'-GAGGCCATGTAGGCCATGAG-3' }\end{array}$ & 256 \\
\hline
\end{tabular}

RT-qPCR, reverse transcription-quantitative polymerase chain reaction; bp, base pairs; iNOS, inducible nitric oxide synthase; Bcl-2, B-cell lymphoma-2.
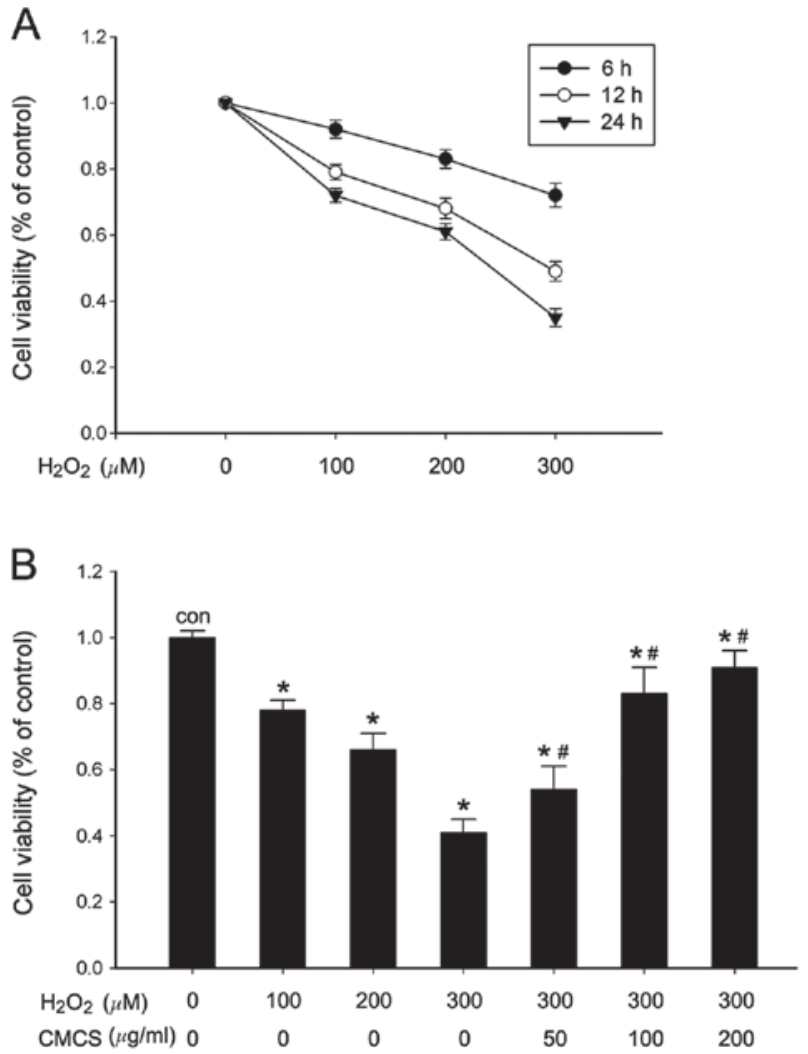

Figure 1. Effect of CMCS on cell viability in $\mathrm{H}_{2} \mathrm{O}_{2}$-induced NP cells as assessed by CCK-8 assay. (A) Time and dose-dependent manner of the effect of $\mathrm{H}_{2} \mathrm{O}_{2}$ on cell viability in NP cells. (B) Effect of CMCS on cell viability in $\mathrm{H}_{2} \mathrm{O}_{2}$-treated NP cells. Cells were treated with $\mathrm{H}_{2} \mathrm{O}_{2}$ for $24 \mathrm{~h}$ with or without 3-h pretreatment with CMCS. ${ }^{*} \mathrm{P}<0.05$ vs. the control group; ${ }^{\#} \mathrm{P}<0.05$ vs. the $300 \mu \mathrm{M} \mathrm{H}_{2} \mathrm{O}_{2}$-induced NP cells group. CMCS, carboxymethylated chitosan; $\mathrm{H}_{2} \mathrm{O}_{2}$, hydrogen peroxide; NP, nucleus pulposus; CCK, cell counting kit.

phenylmethylsulphonyl fluoride, $10 \mu \mathrm{g} / \mathrm{ml}$ leupeptin and $10 \mu \mathrm{g} / \mathrm{ml}$ aprotinin. Lysates were subsequently centrifuged at $13,000 \mathrm{x} \mathrm{g}$ for $15 \mathrm{~min}$ and the supernatant was collected for protein analysis. Sample protein concentration was determined using a commercial bicinchoninic acid protein assay kit (Pierce Biotechnology, Inc., Rockford, IL, USA). Equal amounts of protein from cell lysates were resuspended in sample buffer (P0015; Beyotime Institute of Biotechnology) containing $62 \mathrm{mM}$ Tris- $\mathrm{HCl}(\mathrm{pH} 6.8), 2 \%$ sodium dodecylsulphate (SDS), $10 \%$ glycerol, $5 \% \beta$-mercaptoethanol and $0.04 \%$ bromphenol blue, then resolved by SDS-PAGE and transferred to polyvinylidene difluoride membranes (EMD Millipore, Billierica, MA, USA). Following brief washing in Tris-buffered saline with Tween-20 (TBST) [25 mM Tris- $\mathrm{HCl}$ ( $\mathrm{pH} 7.5$ ), $50 \mathrm{mM} \mathrm{NaCl}, 0.1 \%$ Tween-20; Beijing Biosntech Co., Beijing, China], the membrane was blocked with $5 \%(\mathrm{w} / \mathrm{v})$ non-fat dried milk in TBST overnight at $4^{\circ} \mathrm{C}$. The membrane was incubated for $3 \mathrm{~h}$ with the appropriate primary antibodies. Following washing with TBST, the membranes were incubated with the respective goat anti-rabbit peroxidase-conjugated secondary (\#7074; Cell Signaling Technology, Inc.) antibodies for $1 \mathrm{~h}$ then washed again with TBST. Immunodetection was accomplished by enhanced chemiluminescence using an enhanced chemiluminescence detection kit for HRP (Pierce Biotechnology, Inc.) followed by autoradiography on Kodak-X-OMAT-AR film (Kodak, Rochester, NY, USA) and performed using a Geliance $200 \mathrm{Gel}$ Imaging system (PerkinElmer, Inc., Rocky Hill, NJ, USA) and GeneSnap software, version 6.08.04 (Syngene, Frederick, MD, USA). Bands were analyzed using the GeneTools software, version 3.07.04 (Syngene). All data are expressed as the relative differences between control and treated cells, subsequent to normalization to the $\beta$-actin expression level.

Statistical analysis. Data are presented as the mean \pm standard error. Differences between groups were compared using one-way analysis of variance on SPSS, version 16.0 (SPSS, Inc., Chicago, IL, USA). $\mathrm{P}<0.05$ was considered to indicate a statistically significant difference. 


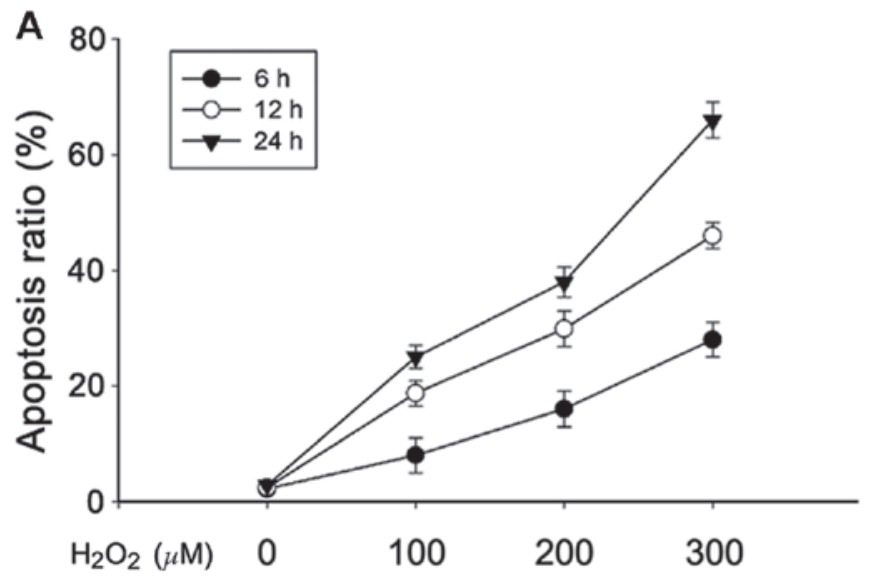

B
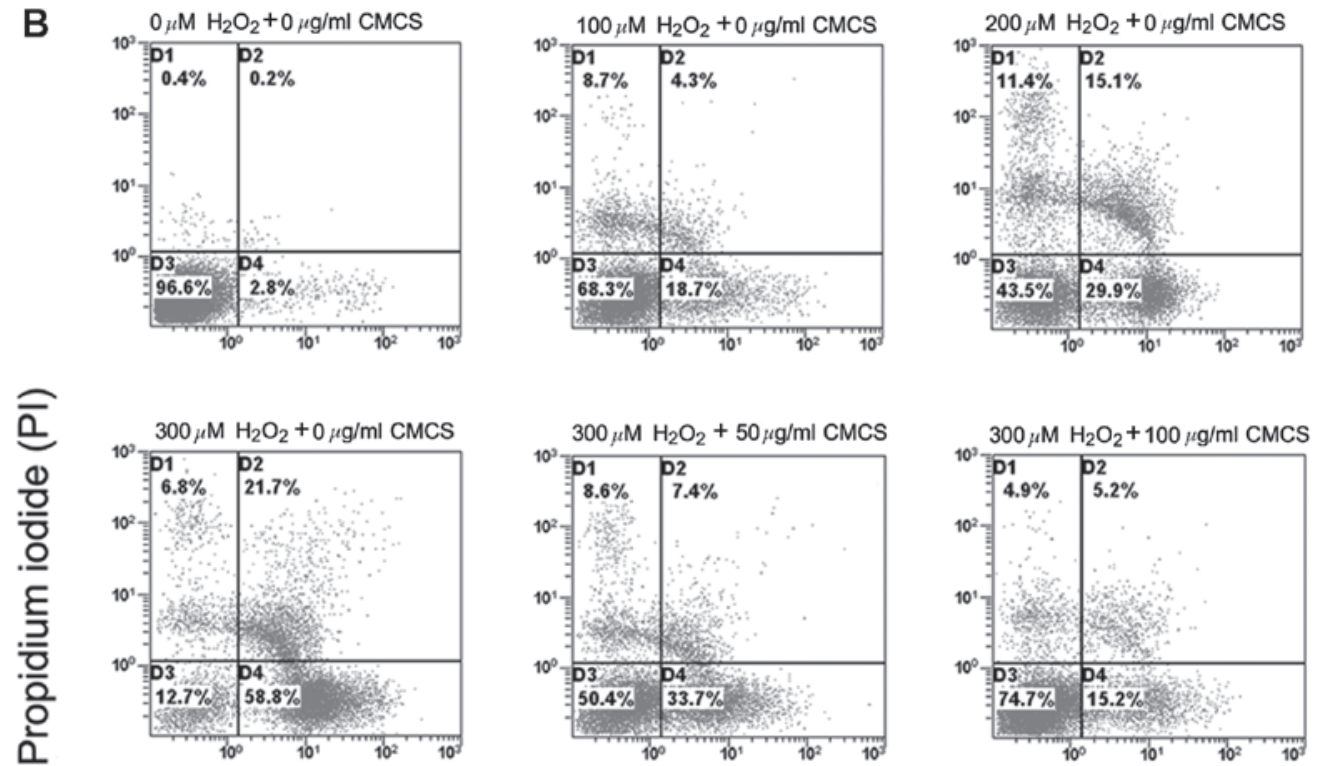

$300 \mu \mathrm{M} \mathrm{H} \mathrm{O}_{2}+200 \mu \mathrm{g} / \mathrm{ml} \mathrm{CMCS}$

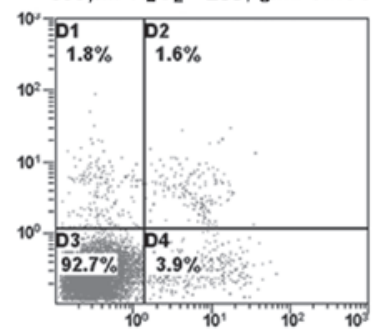

Annexin V-FITC

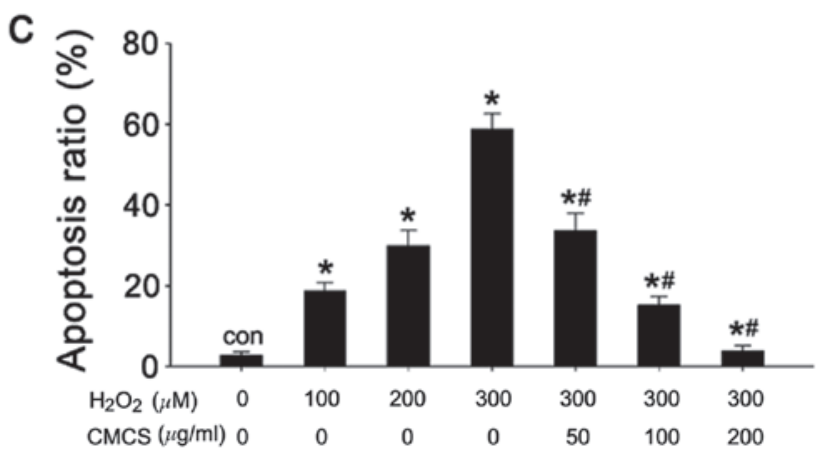

Figure 2. Effect of CMCS on apoptosis in $\mathrm{H}_{2} \mathrm{O}_{2}$-treated NP cells. (A) Time- and dose-dependent manner of the effect of $\mathrm{H}_{2} \mathrm{O}_{2}$ on apoptotic rates in NP cells. (B) Percentage distribution graphs displaying the effect of CMCS on apoptotic rates in $\mathrm{H}_{2} \mathrm{O}_{2}$-treated NP cells. (C) HIstogram summarizing percentages of apoptotic cells in each group following $24-\mathrm{h} \mathrm{H}_{2} \mathrm{O}_{2}$ exposure with or without 3 -h CMCS pretreatment. ${ }^{*} \mathrm{P}<0.05$ vs. the control group; ${ }^{\#} \mathrm{P}<0.05$ vs. the $300 \mu \mathrm{M}$ $\mathrm{H}_{2} \mathrm{O}_{2}$-induced group. CMCS, carboxymethylated chitosan; $\mathrm{H}_{2} \mathrm{O}_{2}$, hydrogen peroxide; NP, nucleus pulposus; V-FITC, V-fluorescein isothiocyanate.

\section{Results}

Effect of CMCS on cell viability in $\mathrm{H}_{2} \mathrm{O}_{2}$-treated $\mathrm{NP}$ cells. The NP cell viability and metabolic activity were analyzed by CCK-8 assay. The results indicated that different concentrations of $\mathrm{H}_{2} \mathrm{O}_{2}$ stimulation $(100,200$ and $300 \mu \mathrm{M})$ were able to reduce the number of metabolically active cells and viability in a time- and dose-dependent manner (Fig. 1A). A significant reduction in cell viability was observed at $24 \mathrm{~h}$ following $300 \mu \mathrm{M} \mathrm{H}_{2} \mathrm{O}_{2}$ exposure (Fig. 1B). However, when NP cells were pretreated with CMCS $(50,100$ or $200 \mu \mathrm{g} / \mathrm{ml})$ for $3 \mathrm{~h}$ and then exposed to $\mathrm{H}_{2} \mathrm{O}_{2}$ for $24 \mathrm{~h}$, cell viability was improved in a dose-dependent manner. The most significant increase was observed in the $200 \mu \mathrm{g} / \mathrm{ml} \mathrm{CMCS-treated} \mathrm{group}$ compared with cell viability following $300 \mu \mathrm{M} \mathrm{H}_{2} \mathrm{O}_{2}$ treatment (Fig. 1B). 

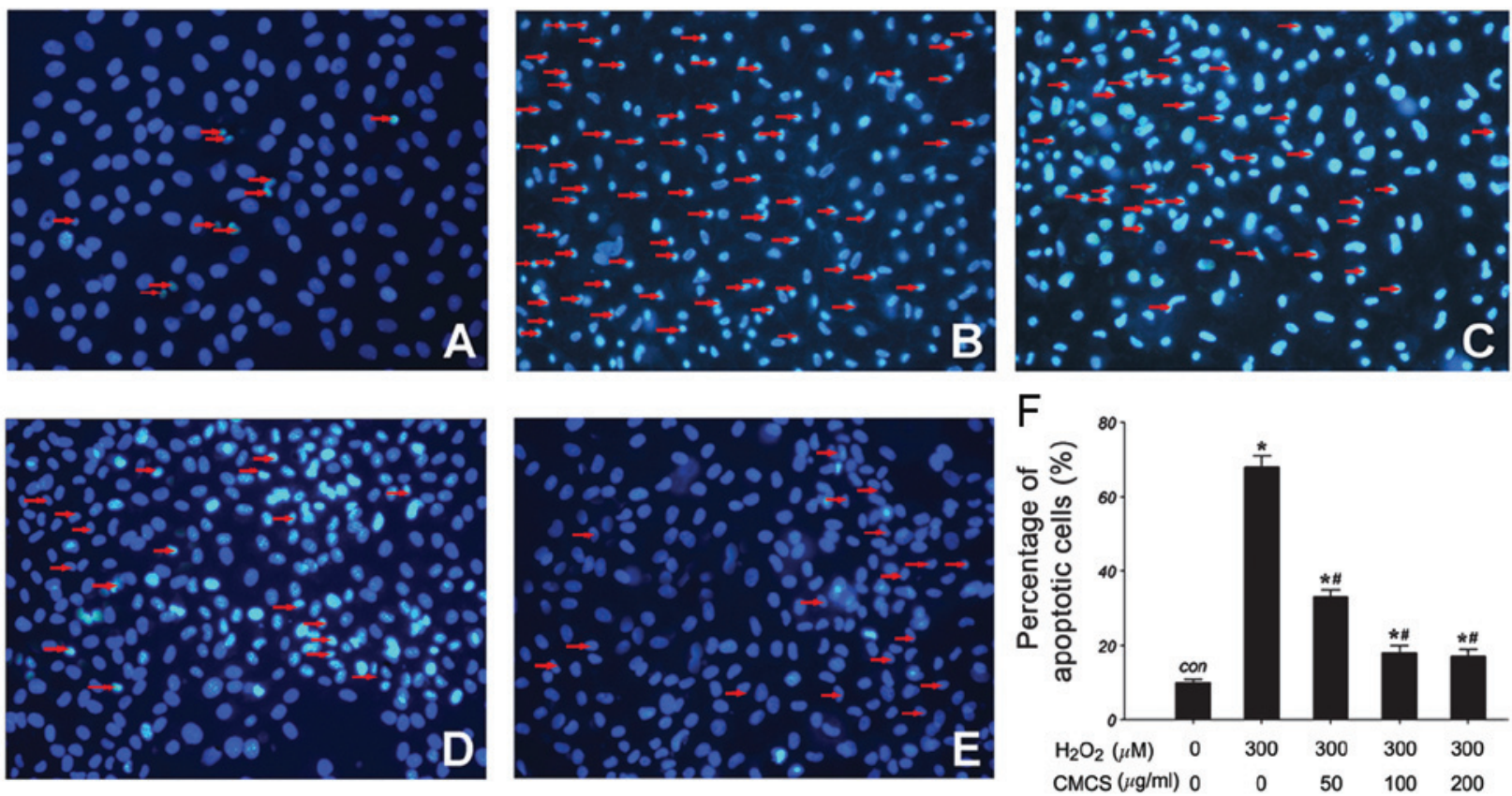

Figure 3. Effect of CMCS on nucleic morphology of $\mathrm{H}_{2} \mathrm{O}_{2}$-treated NP cells. NP cells were incubated with $\mathrm{H}_{2} \mathrm{O}_{2}$ with or without CMCS pretreatment then stained with Hoechst 33342 to detect apoptotic morphology. (A) Control untreated group; (B) $300 \mu \mathrm{M} \mathrm{H}_{2} \mathrm{O}_{2}$; (C) $300 \mu \mathrm{M} \mathrm{H} \mathrm{O}_{2}+50 \mu \mathrm{g} / \mathrm{ml} \mathrm{CMCS}$; (D) $300 \mu \mathrm{M}$ $\mathrm{H}_{2} \mathrm{O}_{2}+100 \mu \mathrm{g} / \mathrm{ml} \mathrm{CMCS}$; and (E) $300 \mu \mathrm{M} \mathrm{H}_{2} \mathrm{O}_{2}+200 \mu \mathrm{g} / \mathrm{ml}$ CMCS. Red arrows represent cells with DNA condensation. (F) The numbers of cells with broken DNA per 30 cells in three different fields in each condition of one experiment were counted and repeated for three different experiments. The mean percentages of positive staining are presented as a histogram. ${ }^{*} \mathrm{P}<0.05$ vs. the control group; ${ }^{\#} \mathrm{P}<0.05$ vs. the $300 \mu \mathrm{M} \mathrm{H}_{2} \mathrm{O}_{2}$-induced group. CMCS, carboxymethylated chitosan; $\mathrm{H}_{2} \mathrm{O}_{2}$, hydrogen peroxide; $\mathrm{NP}$, nucleus pulposus.
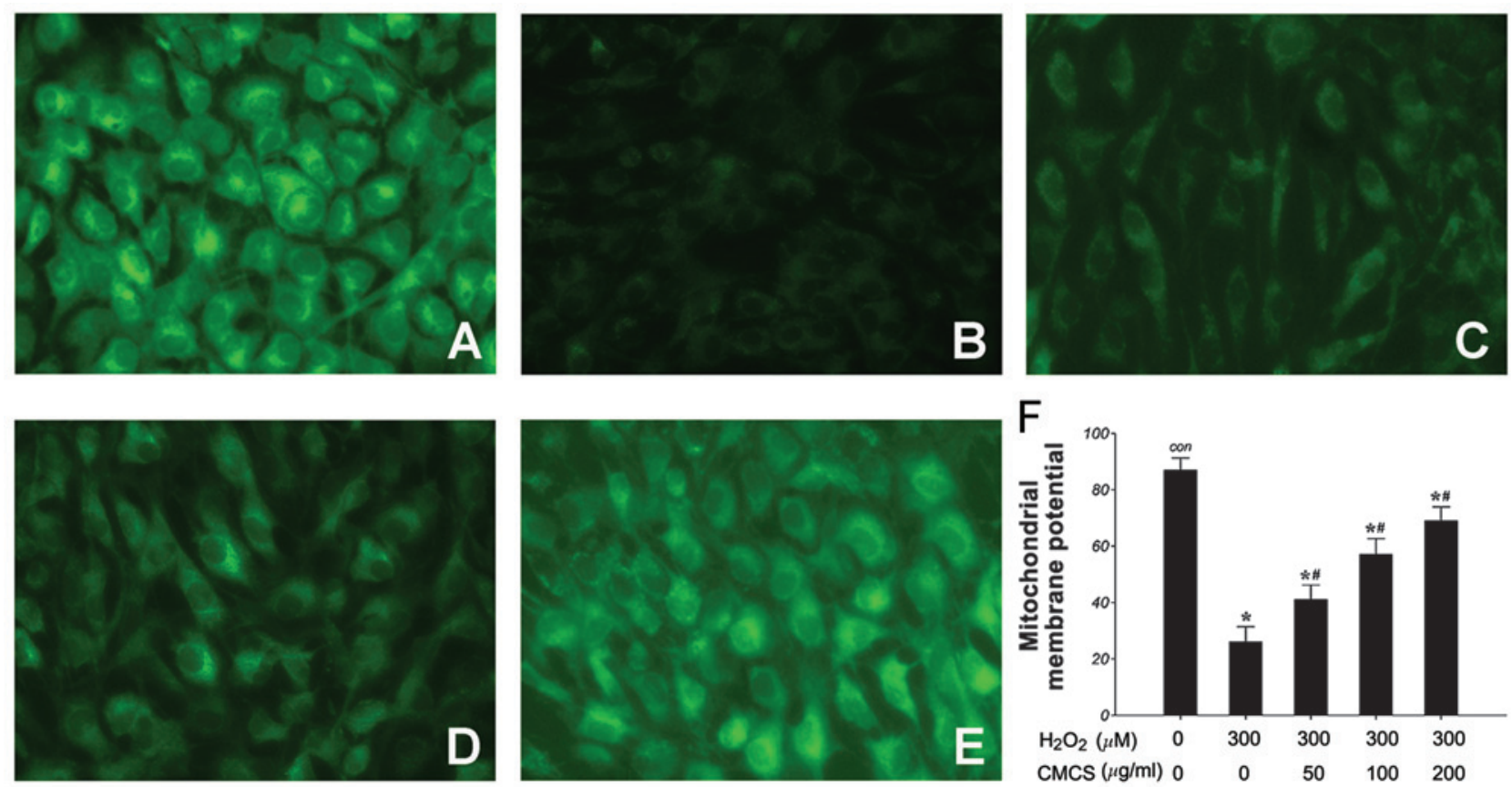

Figure 4. Effect of CMCS on mitochondrial membrane potential $(\Delta \Psi \mathrm{m})$ in $\mathrm{H}_{2} \mathrm{O}_{2}$-exposed NP cells. NP cells were incubated with $\mathrm{H}_{2} \mathrm{O}_{2}$ or $\mathrm{H}_{2} \mathrm{O}_{2} / C M C S$ treatment and then stained with Rho1 23 to detect the $\Delta \Psi \mathrm{m}$. (A) Control untreated group; (B) $300 \mu \mathrm{M} \mathrm{H}_{2} \mathrm{O}_{2}$; (C) $300 \mu \mathrm{M} \mathrm{H} \mathrm{O}_{2}+50 \mu \mathrm{g} / \mathrm{ml} \mathrm{CMCS}$; (D) $300 \mu \mathrm{M}$ $\mathrm{H}_{2} \mathrm{O}_{2}+100 \mu \mathrm{g} / \mathrm{ml} \mathrm{CMCS}$; and (E) $300 \mu \mathrm{M} \mathrm{H}_{2} \mathrm{O}_{2}+200 \mu \mathrm{g} / \mathrm{ml} \mathrm{CMCS}$. (F) The $\Delta \Psi \mathrm{m}$ was assessed by Rho1 23 fluorescence intensity. "P $<0.05$ vs. the control group; ${ }^{\prime \prime} \mathrm{P}<0.05$ vs. the $300 \mu \mathrm{M} \mathrm{H}_{2} \mathrm{O}_{2}$-induced group. CMCS, carboxymethylated chitosan; $\mathrm{H}_{2} \mathrm{O}_{2}$, hydrogen peroxide; NP, nucleus pulposus; Rho123, rhodamine123.

Effect of CMCS on apoptosis in $\mathrm{H}_{2} \mathrm{O}_{2}$-treated NP cells. The rate of apoptosis was quantified using flow cytometry with annexin V-FITC/PI staining. As presented in Fig. 2A, $\mathrm{H}_{2} \mathrm{O}_{2}$ exposure increased the apoptotic rates of the NP cells compared with the control cells, in a time- and dose-dependent manner. The apoptotic ratios were 18.7, 29.9 and 58.8\% in 100, 200 and $300 \mu \mathrm{M} \mathrm{H}_{2} \mathrm{O}_{2}$-treated NP cells respectively, while it was $2.8 \%$ in control cells (Fig. 2B and C). CMCS significantly inhibited 
A

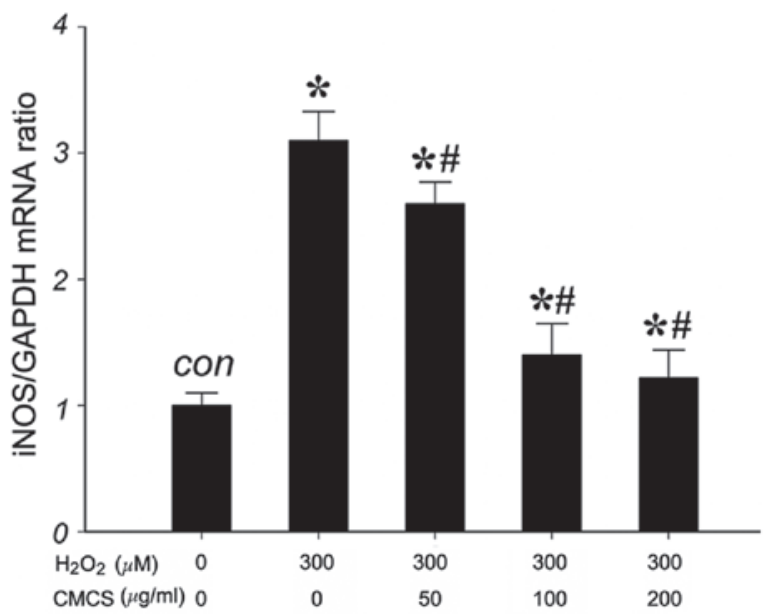

B
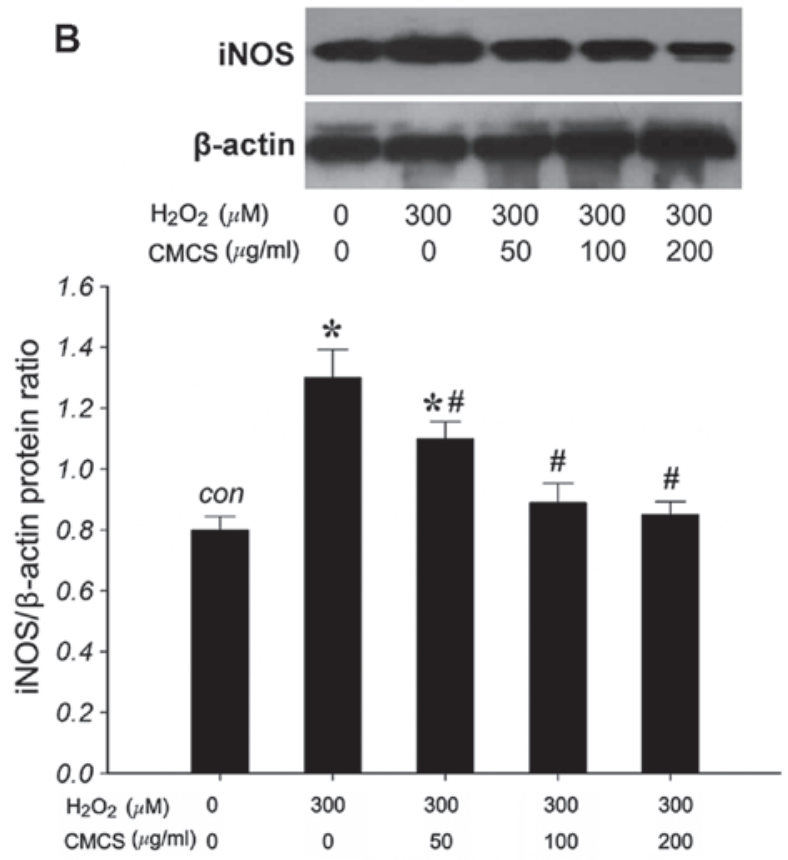

Figure 5. Effects of CMCS on iNOS expression in $\mathrm{H}_{2} \mathrm{O}_{2}$-treated NP cells. (A) RT-qPCR analysis of iNOS mRNA expression following $\mathrm{H}_{2} \mathrm{O}_{2}$-induced apoptosis with or without CMCS pretreatment. The data were normalized to GAPDH expression and presented as a percentage of the level in untreated cellular controls. (B) Top: Western blot analysis of iNOS protein expression following $\mathrm{H}_{2} \mathrm{O}_{2}$-induced apoptosis with or without CMCS pretreatment before apoptotic induction. Bottom: Quantitative analysis of the representative western blot. Data were normalized to $\beta$-actin expression and presented as a percentage of the level in untreated cellular controls. ${ }^{*} \mathrm{P}<0.05$ vs. the control group; ${ }^{\prime \prime} \mathrm{P}<0.05$ vs. the $300 \mu \mathrm{M} \mathrm{H}_{2} \mathrm{O}_{2}$-induced group. CMCS, carboxymethylated chitosan; iNOS, inducible oxide synthase; $\mathrm{H}_{2} \mathrm{O}_{2}$, hydrogen peroxide; NP, nucleus pulposus; RT-qPCR, reverse transcription quantitative polymerase chain reaction.

$\mathrm{H}_{2} \mathrm{O}_{2}$-induced apoptosis in a dose-dependent manner; treatment with 50, 100 and $200 \mu \mathrm{g} / \mathrm{ml} \mathrm{CMCS}$ in $\mathrm{H}_{2} \mathrm{O}_{2}$-treated NP cells resulted in apoptotic ratios of $33.7,15.2$ and $3.9 \%$, respectively.

Effect of CMCS on nucleic morphology in $\mathrm{H}_{2} \mathrm{O}_{2}$-treated $N P$ cells. Subsequent to culture with $\mathrm{H}_{2} \mathrm{O}_{2}$ or the $\mathrm{H}_{2} \mathrm{O}_{2} / C M C S$ combination, morphological changes in the NP cells were observed by Hoechst 33342 staining. As presented in Fig. 3, in the control group, NP cell nuclei were round and stained homogeneously with Hoechst 33342 (Fig. 3A). In $\mathrm{H}_{2} \mathrm{O}_{2}$-treated NP cells, a considerable proportion of cells displayed characteristics of apoptosis with condensed and fragmented nuclei (Fig. 3B). Treatment with 50, 100 and $200 \mu \mathrm{g} / \mathrm{ml} \mathrm{CMCS} \mathrm{led}$ to a significant reduction in the number of apoptotic cells with fragmented nuclei (Fig. 3C-F). These results suggest that CMCS is able to inhibit the $\mathrm{H}_{2} \mathrm{O}_{2}$-induced nucleic morphological changes in NP cells.

Effects of CMCS on $\triangle \Psi$ m in $\mathrm{H}_{2} \mathrm{O}_{2}$-treated $\mathrm{NP}$ cells. It has been reported that $\mathrm{CMCS}$ may prevent mitochondrial oxidative stress. Thus, the effects of $\mathrm{H}_{2} \mathrm{O}_{2}$ and the $\mathrm{H}_{2} \mathrm{O}_{2}$ /CMCS combination on $\Delta \Psi \mathrm{m}$ were examined as a marker of mitochondrial function. $\Delta \Psi \mathrm{m}$ was assessed using the Rho123 fluorescent dye, the intensity of which reflects mitochondrial function. As demonstrated in Fig. 4, $300 \mu \mathrm{M} \mathrm{H}_{2} \mathrm{O}_{2}$ induced a significant reduction in $\Delta \Psi \mathrm{m}$ following treatment for $24 \mathrm{~h}$ compared with the control group (Fig. 4A and B). Treatment with CMCS was demonstrated to prevent this reduction in a dose-dependent manner (Fig. 4C-F). These results suggest that CMCS may be able to protect mitochondrial function in NP cells.

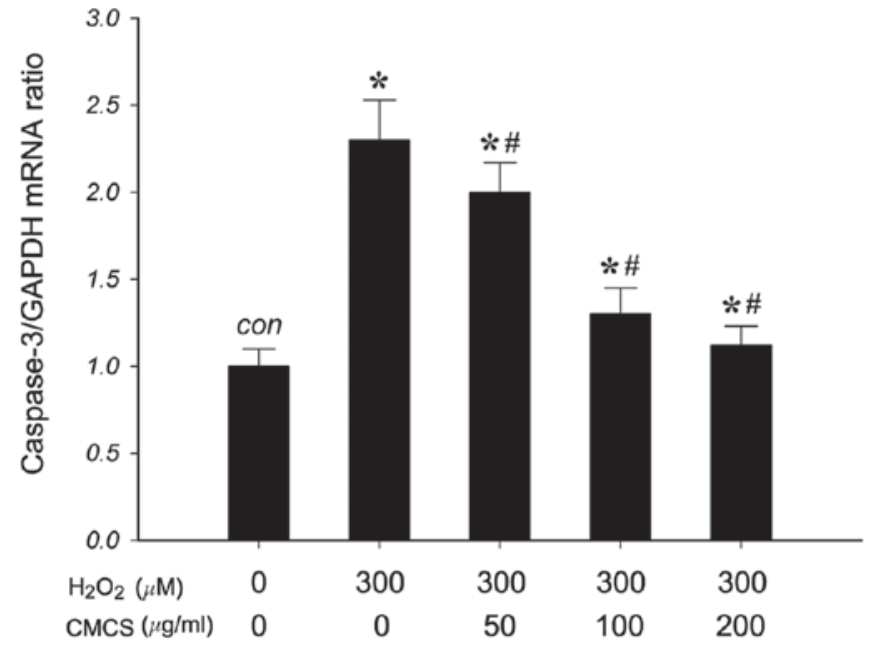

Figure 6. Effect of CMCS on caspase-3 expression level in $\mathrm{H}_{2} \mathrm{O}_{2}$-induced NP cells. RT-qPCR analysis of caspase- 3 mRNA expression following $\mathrm{H}_{2} \mathrm{O}_{2}$ exposure with or without CMCS pretreatment. Data were normalized to GAPDH expression and presented as a percentage of the level in untreated cellular controls. ${ }^{*} \mathrm{P}<0.05$ vs. the control group; ${ }^{\#} \mathrm{P}<0.05$ vs. the $300 \mu \mathrm{M}$ $\mathrm{H}_{2} \mathrm{O}_{2}$-induced group. CMCS, carboxymethylated chitosan; $\mathrm{H}_{2} \mathrm{O}_{2}$, hydrogen peroxide; NP, nucleus pulposus; RT-qPCR, reverse transcription quantitative polymerase chain reaction.

Effect of CMCS on the expression level of iNOS in $\mathrm{H}_{2} \mathrm{O}_{2}$-treated $\mathrm{NP}$ cells. To investigate the effects of CMCS on the expression of iNOS in $\mathrm{H}_{2} \mathrm{O}_{2}$-treated NP cells, the mRNA and protein levels of iNOS were measured. RT-qPCR results indicated that $300 \mu \mathrm{M} \mathrm{H}_{2} \mathrm{O}_{2}$ significantly increased the iNOS/GAPDH mRNA ratio compared with that of 
A

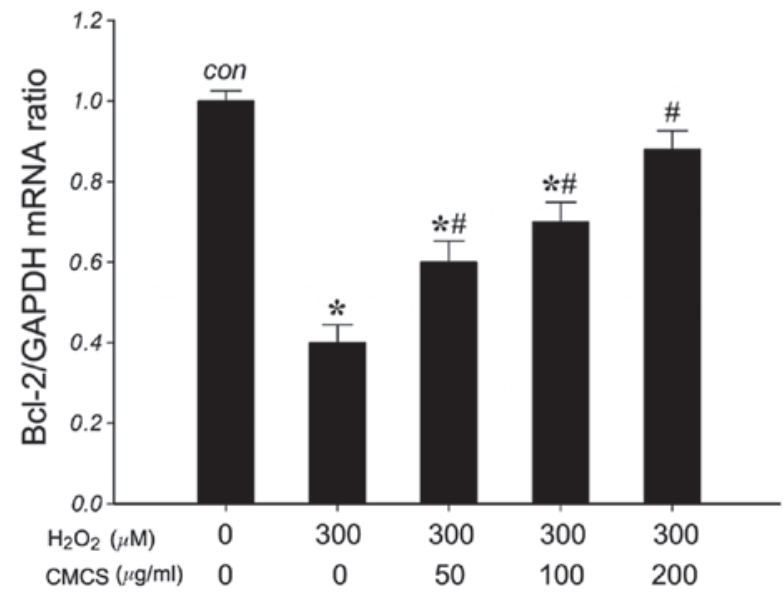

B
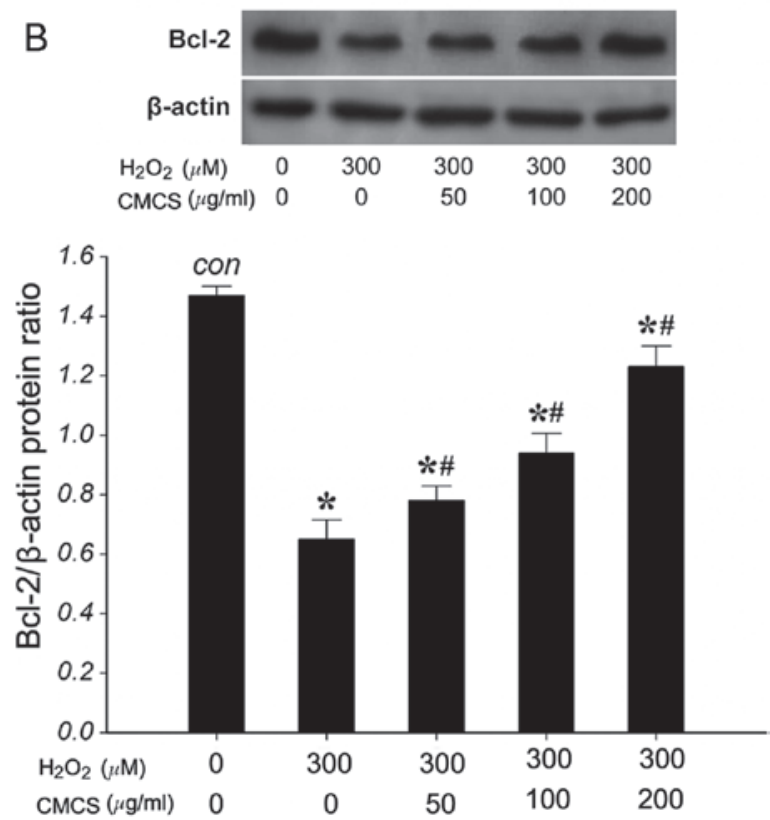

Figure 7. Effects of CMCS on Bcl-2 expression in $\mathrm{H}_{2} \mathrm{O}_{2}$-treated NP cells. (A) RT-qPCR analysis of Bcl-2 mRNA expression levels following $\mathrm{H}_{2} \mathrm{O}_{2}$ exposure with or without CMCS pretreatment. The data were normalized to GAPDH expression and presented as a percentage of the level in untreated cellular controls. (B) Top: Western blot analysis of Bcl-2 protein expression following $\mathrm{H}_{2} \mathrm{O}_{2}$-induced apoptosis with or without CMCS pretreatment. Bottom: Densitometry analysis of the representative western blot. Data were normalized to $\beta$-actin expression and presented as a percentage of untreated cellular controls. * $\mathrm{P}<0.05$ vs. the control group; ${ }^{\#} \mathrm{P}<0.05$ vs. the $300 \mu \mathrm{M} \mathrm{H}_{2} \mathrm{O}_{2}$-treated group. CMCS, carboxymethylated chitosan; Bcl, B-cell lymphoma; $\mathrm{H}_{2} \mathrm{O}_{2}$, hydrogen peroxide; $\mathrm{NP}$, nucleus pulposus; RT, reverse transcription; qPCR, quantitative polymerase chain reaction.

the control group (Fig. 5A). However, treatment with 50, 100 and $200 \mu \mathrm{g} / \mathrm{ml} \mathrm{CMCS} \mathrm{was} \mathrm{able} \mathrm{to} \mathrm{inhibit} \mathrm{this} \mathrm{increase}$ in a dose-dependent manner. The expression of iNOS protein (130 kDa) was detected by western blot analysis (Fig. 5B). $\mathrm{H}_{2} \mathrm{O}_{2}$ exposure significantly increased the iNOS protein level compared with that of the control group, and treatment with 50, 100 and $200 \mu \mathrm{g} / \mathrm{ml} \mathrm{CMCS}$ was able to inhibit this increase in a dose-dependent manner. These results suggest that CMCS is able to inhibit the $\mathrm{H}_{2} \mathrm{O}_{2}$-induced increase in NP cell iNOS mRNA and protein levels.

Effect of CMCS on caspase-3 mRNA expression in $\mathrm{H}_{2} \mathrm{O}_{2}$-treated $\mathrm{NP}$ cells. To investigate the effects of CMCS on the expression of caspase-3 (a mediator of apoptosis) in $\mathrm{H}_{2} \mathrm{O}_{2}$-treated NP cells, the mRNA levels of caspase- 3 were measured. As presented in Fig. 6, RT-qPCR results indicated that $300 \mu \mathrm{M} \mathrm{H}_{2} \mathrm{O}_{2}$ exposure significantly increased the level of caspase- 3 mRNA compared with that of the control group. Treatment with 50, 100 and $200 \mu \mathrm{g} / \mathrm{ml} \mathrm{CMCS} \mathrm{was} \mathrm{able} \mathrm{to}$ inhibit this increase in a dose-dependent manner. These results suggested that CMCS can inhibit the $\mathrm{H}_{2} \mathrm{O}_{2}$-induced increase in the level of caspase- 3 in NP cells.

Effect of CMCS on the expression levels of Bcl-2 in $\mathrm{H}_{2} \mathrm{O}_{2}$-treated $N P$ cells. To investigate the effects of CMCS on the expression of Bcl-2 in $\mathrm{H}_{2} \mathrm{O}_{2}$-treated NP cells, the mRNA and protein levels of $\mathrm{Bcl}-2$ were measured. RT-qPCR results indicated that $300 \mu \mathrm{M} \mathrm{H}_{2} \mathrm{O}_{2}$ significantly reduced the level of Bcl-2 mRNA compared with that of the control group (Fig. 7A). However, treatment with 50, 100 and $200 \mu \mathrm{g} / \mathrm{ml}$ CMCS was able to inhibit this reduction in a dose-dependent manner. The expression of Bcl-2 protein (26 kDa) was detected by western blot

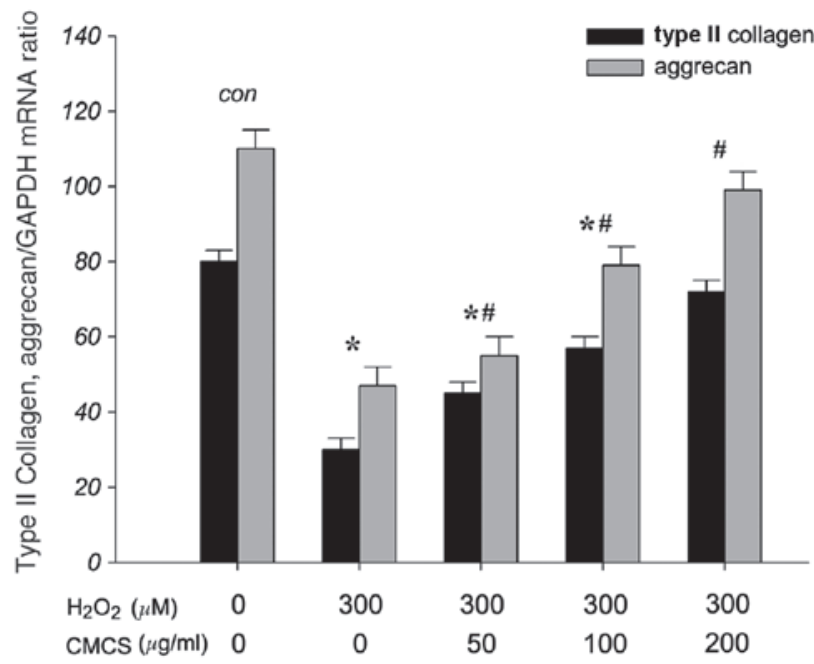

Figure 8. Effects of CMCS on ECM secretion in $\mathrm{H}_{2} \mathrm{O}_{2}$-induced NP cells. The RT-qPCR of type II collagen and aggrecan mRNA expression following $\mathrm{H}_{2} \mathrm{O}_{2}$ exposure with or without CMCS pretreatment. Data were normalized to GAPDH expression and presented as a percentage of the level in untreated cellular controls. ${ }^{*} \mathrm{P}<0.05$ vs. the control group; ${ }^{*} \mathrm{P}<0.05$ vs. the $300 \mu \mathrm{M}$ $\mathrm{H}_{2} \mathrm{O}_{2}$-treated group. CMCS, carboxymethylated chitosan; ECM, extracellular matrix; $\mathrm{H}_{2} \mathrm{O}_{2}$, hydrogen peroxide; NP, nucleus pulposus; RT, reverse transcription; qPCR, quantitative polymerase chain reaction.

analysis. As presented in Fig. 7B, $300 \mu \mathrm{M} \mathrm{H}_{2} \mathrm{O}_{2}$ significantly reduced the level of $\mathrm{Bcl}-2$ protein compared with that in the control group. However, treatment with 50, 100 and $200 \mu \mathrm{g} / \mathrm{ml}$ CMCS was able to inhibit the reduction in $\mathrm{Bcl}-2$ protein in $\mathrm{H}_{2} \mathrm{O}_{2}$-treated NP cells in a dose-dependent manner. These results suggest that CMCS is able to inhibit the $\mathrm{H}_{2} \mathrm{O}_{2}$-induced reduction of Bcl-2 mRNA and protein in NP cells. 
CMCS increases ECM production in $\mathrm{H}_{2} \mathrm{O}_{2}$-treated NP cells. To investigate the effects of CMCS on the secretion of ECM components, including collagen type II and aggrecan, in $\mathrm{H}_{2} \mathrm{O}_{2}$-exposed NP cells, the mRNA levels of type II collagen and aggrecan were measured. As presented in Fig. 8, RT-qPCR results indicated that $300 \mu \mathrm{M} \mathrm{H}_{2} \mathrm{O}_{2}$ significantly reduced the levels of type II collagen and aggrecan mRNA compared with those of the control group. However, treatment with 50, 100 and $200 \mu \mathrm{g} / \mathrm{ml} \mathrm{CMCS}$ was able to inhibit this reduction in a dose-dependent manner. These results suggest that CMCS is able to protect the secretion of type II collagen and aggrecan in the apoptotic environment.

\section{Discussion}

The present study demonstrated that CMCS can protect or rescue NP cells in vitro from undergoing apoptosis following $\mathrm{H}_{2} \mathrm{O}_{2}$ exposure, and that the mechanisms of this protection may involve caspase- 3 and $\mathrm{Bcl}-2$ activation and mitochondrial function.

IVD degeneration is considered to be associated with genetic factors, in addition to excessive mechanical loading, which together alter the biomechanical properties of the IVD. Although the precise mechanism of disc degeneration remains unclear, it has been suggested in previous studies that apoptosis or programmed cell death of IVD cells may be one of the key steps in disc degeneration (25).

In the present study, it was observed that treatment of the NP cells with CMCS prior to exposure to $\mathrm{H}_{2} \mathrm{O}_{2}$ resulted in significantly increased cell survival. This was accompanied by the finding that CMCS, prophylactively added to the NP cell cultures, demonstrated a protective effect on the NP cells regarding the $\mathrm{H}_{2} \mathrm{O}_{2}$-induced reduction in viability. These results were consistent with previous observations that CMCS and chitosan were able to protect chondrocytes, endometriotic cells, vein endothelial cells and astrocytes from apoptosis $(19,26-28)$.

There are numerous factors involved in apoptotic cascades. Caspases, the 'key executioners' of apoptosis, are a family of cysteine proteases capable of cleaving essential cellular substrates with aspartate residues (29). Caspases-8, -9 and -10 are involved in the initiation and amplification of apoptosis, while caspases-3, -6 and -7 are involved in executing the apoptotic program and cell death (30). Caspase-3, the most prominent effective caspase, is localized downstream in the caspase cascade and represents the main effective molecule in apoptosis. It irreversibly executes programmed cell death. Caspase- 3 is located in the cellular cytoplasm in its inactive form in the normal microenvironment, but it is auto-proteolytically cleaved into an active form of the enzyme under apoptotic conditions $(31,32)$. Apoptosis is triggered by several stimuli resulting in several apoptotic pathways. Rannou et al (33) demonstrated that mechanical overload induces disc degeneration via a caspase-9-dependent apoptotic pathway, suggesting that disc cell apoptosis is the primary cause of disc degeneration. Others have indicated that caspase- 3 acts as the main apoptosis effector, and it may be the therapeutic target for regulation of IVD degeneration (34). In the present study, $\mathrm{H}_{2} \mathrm{O}_{2}$-exposed NP cells exhibited an increased level of intracellular caspase-3 mRNA and caspase-3 activity. Treatment with CMCS significantly inhibited the caspase-3 activity generated by $\mathrm{H}_{2} \mathrm{O}_{2}$. The results of the current study suggest that CMCS inhibits caspase-3 activity and the anti-apoptotic effect of CMCS is at least partly mediated via caspase-3 enzymatic inhibition.

There are two major signaling pathways controlling the initiation of apoptosis in mammals. The extrinsic pathway involves engagement of cell-surface death receptors by ligands that belong to the TNF receptor superfamily and the consequent activation of caspase-8. The intrinsic pathway involves caspase- 9 as the initiator, and originates from the mitochondria. Stressed mitochondria release a set of molecules, including cytochrome- $c$ and Apaf-1, to form the apoptosome molecular cluster that activates caspase-9 and its downstream effector, caspase-3. Park et al (17) examined human herniated lumbar disc tissues with the use of immunohistochemical staining and western blot analysis to determine the presence of several proteins associated with apoptosis. They established that the proteins associated with the intrinsic pathway were stained positive in all samples. The results of their study suggest that disc cells participate in the intrinsic pathway, and subsequently undergo apoptotic cell death through mitochondrial involvement.

In the intrinsic pathway, Bcl-2 prevents or delays apoptotic induction by a large variety of stimuli in various cell types (35). Molecular intervention at the level of Bcl-2 in the apoptotic pathway, therefore, has the potential to enhance cell survival. Although the apoptotic cascade remains to be fully elucidated, overexpression of $\mathrm{Bcl}-2$ has previously been demonstrated to prevent the release of apoptotic induction factors and the subsequent activation of caspase-3 (36). Sudo and Minami (37) indicated that Bcl-2 overexpression in IVD cells effectively prevented in vitro apoptotic cell death.

Mitochondria are complex organelles that oxidize a wide range of metabolic intermediates, and their impairment has been linked to various disorders (38). Changes in the permeability and structure of the mitochondrial membrane may lead to apoptosis.

An impaired $\Delta \Psi \mathrm{m}$ reflects the malfunction of mitochondria subsequent to $\mathrm{H}_{2} \mathrm{O}_{2}$ exposure. It also implies the decoupling of oxidative phosphorylation, accumulation of reactive oxygen species, and a reduction in cytoplasmic ATP levels. Mitochondria synthesize ATP to maintain the vital metabolism conducted in eukaryotic cells. In the early stages of cell apoptosis, the breakdown of $\Delta \Psi \mathrm{m}$ regulation is one of the earliest features preceding nuclear condensation and apoptotic body formation. Data from the current study demonstrate that the $\Delta \Psi \mathrm{m}$ was lower in the $\mathrm{H}_{2} \mathrm{O}_{2}$-treated NP cells compared with the control group, and this effect is partly abolished by CMCS in a dose-dependent manner. This indicates that the inhibitory effect of CMCS on NP cell apoptosis is associated with its protection of mitochondrial function. CMCS may protect mitochondrial function through inhibiting the reduction of $\Delta \Psi \mathrm{m}$, and thus, promote the synthesis of ATP, inhibited by $\mathrm{H}_{2} \mathrm{O}_{2}$ exposure.

In agreement with previous studies, the current study identified a restorative effect of CMCS on $\mathrm{H}_{2} \mathrm{O}_{2}$-induced ECM reduction in disc cells in vitro. The anti-apoptotic (anticatabolic) effects of CMCS and its potential to enhance ECM production (anabolic effect) potentially make it an excellent molecular candidate to break the cycle of degenerative cytokines that lead to further progression of IVD degeneration. 
In conclusion, the current study demonstrated that CMCS can protect NP cells from $\mathrm{H}_{2} \mathrm{O}_{2}$-induced cell apoptosis. The mechanism of CMCS in protecting NP cells from apoptosis remains unknown, but appears to be partly mediated via caspase-3 enzymatic inhibition/Bcl-2 activation, in addition to diminishing nitric oxide production and protecting mitochondrial function. These data suggest one possible mechanism of CMCS rescue in IVD degeneration, and support the therapeutic rationale for CMCS utilization in human disc degeneration.

\section{Acknowledgements}

The current study was supported by the National Natural Science Foundation of China (grant nos. 81301056 and 30801166).

\section{References}

1. Chen WH, Liu HY, Lo WC, Wu SC, Chi CH, Chang HY, et al: Intervertebral disc regeneration in an ex vivo culture system using mesenchymal stem cells and platelet-rich plasma. Biomaterials 30: 5523-5533, 2009.

2. Kalichman L and Hunter DJ: The genetics of intervertebral disc degeneration. Familial predisposition and heritability estimation. Joint Bone Spine 75: 383-387, 2008

3. Schultz DS, Rodriguez AG, Hansma PK and Lotz JC: Mechanical profiling of intervertebral discs. J Biomech 42: 1154-1157, 2009.

4. Zhao CQ, Wang LM, Jiang LS and Dai LY: The cell biology of intervertebral disc aging and degeneration. Ageing Res Rev 6: 247-261, 2007.

5. Zhao CQ, Jiang LS and Dai LY: Programmed cell death in intervertebral disc degeneration. Apoptosis 11: 2079-2088, 2006.

6. Setton LA and Chen J: Cell mechanics and mechanobiology in the intervertebral disc. Spine (Phila Pa 1976) 29: 2710-2723, 2004.

7. Aguiar DJ, Johnson SL and Oegema TR: Notochordal cells interact with nucleus pulposus cells: regulation of proteoglycan synthesis. Exp Cell Res 246: 129-137, 1999.

8. Iwashina T, Mochida J, Miyazaki T, Watanabe T, Iwabuchi S, Ando K, Hotta T and Sakai D: Low-intensity pulsed ultrasound stimulates cell proliferation and proteoglycan production in rabbit intervertebral disc cells cultured in alginate. Biomaterials 27: 354-361, 2006

9. Vonk LA, Kroeze RJ, Doulabi BZ, Hoogendoorn RJ, Huang C, Helder MN, Everts V and Bank RA: Caprine articular, meniscus and intervertebral disc cartilage: an integral analysis of collagen network and chondrocytes. Matrix Biol 29: 209-218, 2010.

10. Hsieh AH and Twomey JD: Cellular mechanobiology of the intervertebral disc: new directions and approaches. J Biomech 43: $137-145,2010$

11. Gruber HE and Hanley EN Jr: Analysis of aging and degeneration of the human intervertebral disc. Comparison of surgical specimens with normal controls. Spine (Phila Pa 1976) 23 751-757, 1998.

12. Kim KW, Ha KY, Lee JS, Rhyu KW, An HS and Woo YK: The apoptotic effects of oxidative stress and antiapoptotic effects of caspase inhibitors on rat notochordal cells. Spine (Phila Pa 1976) 32: 2443-2448, 2007.

13. Nosseri C, Coppola S and Ghibelli L: Possible involvement of poly(ADP-ribosyl) polymerase in triggering stress-induced apoptosis. Exp Cell Res 212: 367-373, 1994.

14. Jiang B, Xiao W, Shi Y,Liu M and XiaoX: Heat shock pretreatment inhibited the release of Smac/DIABLO from mitochondria and apoptosis induced by hydrogen peroxide in cardiomyocytes and C2C12 myogenic cells. Cell Stress Chaperones 10: 252-262, 2005.

15. Nagata S: Apoptotic DNA fragmentation. Exp Cell Res 256: 12-18, 2000

16. Singh M, Sharma H and Singh N: Hydrogen peroxide induces apoptosis in HeLa cells through mitochondrial pathway. Mitochondrion 7: 367-373, 2007.

17. Park JB, Lee JK, Park SJ, Kim KW and Riew KD: Mitochondrial involvement in fas-mediated apoptosis of human lumbar disc cells. J Bone Joint Surg Am 87: 1338-1342, 2005.
18. Liu SQ, Qiu B, Chen LY, Peng H and Du YM: The effects of carboxymethylated chitosan on metalloproteinase-1, -3 and tissue inhibitor of metalloproteinase-1 gene expression in cartilage of experimental osteoarthritis. Rheumatol Int 26: 52-57, 2005.

19. Chen Q, Liu SQ, Du YM, Peng H and Sun LP: Carboxymethyl-chitosan protects rabbit chondrocytes from interleukin-1beta-induced apoptosis. Eur J Pharmacol 541: 1-8, 2006.

20. He B, Liu SQ, Chen Q, Li HH, Ding WJ and Deng M: Carboxymethylated chitosan stimulates proliferation of Schwann cells in vitro via the activation of the ERK and Akt signaling pathways. Eur J Pharmacol 667: 195-201, 2011

21. Tao HY, He B, Liu SQ, Wei AL, Tao FH, Tao HL, Deng WX, $\mathrm{Li} \mathrm{HH}$ and Chen Q: Effect of carboxymethylated chitosan on the biosynthesis of NGF and activation of the Wnt/ $\beta$-catenin signaling pathway in the proliferation of Schwann cells. Eur J Pharmacol 702: 85-92, 2013.

22. Risbud MV, Guttapalli A, Stokes DG, Hawkins D, Danielson KG, Schaer TP, Albert TJ and Shapiro IM: Nucleus pulposus cells express HIF-1 alpha under normoxic culture conditions: a metabolic adaptation to the intervertebral disc microenvironment. J Cell Biochem 98: 152-159, 2006.

23. Cheng YH, Yang SH and Lin FH: Themosensitive chitosan-gelatin-glycerol phosphate hydrogel as a controlled release system of ferulic acid for nucleus pulposus regeneration. Biomaterials 32: 6953-6961, 2011.

24. Tonomura H, Takahashi KA, Mazda O, Arai Y, Inoue A, Terauchi R, Shin-Ya M, Kishida T, Imanishi J and Kubo T: Glutamine protects articular chondrocytes from heat stress and NO-induced apoptosis with HSP70 expression. Osteoarthritis Cartilage 14: 545-553, 2006.

25. Kim KW, Ha KY, Lee JS, Rhyu KW, An HS and Woo YK: The apoptotic effects of oxidative stress and antiapoptotic effects of caspase inhibitors on rat notochordal cells. Spine (Phila Pa 1976) 32: 2443-2448, 2007.

26. Wang YC, Fu RH, Hsieh HJ, Chao HT and Kao SH: Polyglycolic acid/chitosan glue and apoptosis of endometriotic cells. Fertil Steril 84: 75-81, 2005.

27. Liu HT, Li WM, Xu G, Li XY, Bai XF, Wei P, Yu C and Du YG: Chitosan oligosaccharides attenuate hydrogen peroxide-induced stress injury in human umbilical vein endothelial cells. Pharmacol Res 59: 167-175, 2009.

28. Koo HN, Jeong HJ, Hong SH, Choi JH, An NH and Kim HM: High molecular weight water-soluble chitosan protects against apoptosis induced by serum starvation in human astrocytes. J Nutr Biochem 13: 245-249, 2002.

29. Earnshaw WC, Martins LM and Kaufmann SH: Mammalian caspases: structure, activation, substrates, and functions during apoptosis. Annu Rev Biochem 68: 383-424, 1999.

30. Ruest LB, Khalyfa A and Wang E: Development-dependent disappearance of caspase-3 in skeletal muscle is post-transcriptionally regulated. J Cell Biochem 86: 21-28, 2002.

31. Budihardjo I, Oliver H,Lutter M, Luo X and Wang X: Biochemical pathways of caspase activation during apoptosis. Annu Rev Cell Dev Biol 15: 269-290, 1999.

32. Thornberry NA and Lazebnik Y: Caspases: enemies within. Science 281: 1312-1316, 1998.

33. Rannou F, Lee TS, Zhou RH, Chin J, Lotz JC, Mayoux-Benhamou MA, Barbet JP, Chevrot A and Shyy JY: Intervertebral disc degeneration: the role of the mitochondrial pathway in annulus fibrosus cell apoptosis induced by overload. Am J Pathol 164: 915-924, 2004

34. Sudo H and Minami A: Caspase 3 as a therapeutic target for regulation of intervertebral disc degeneration in rabbits. Arthritis Rheum 63: 1648-1657, 2011.

35. Burlacu A: Regulation of apoptosis by $\mathrm{Bcl}-2$ family proteins. J Cell Mol Med 7: 249-257, 2003.

36. Zhao H, Yenari MA, Cheng D, Sapolsky RM and Steinberg GK: Bcl-2 overexpression protects against neuron loss within the ischemic margin following experimental stroke and inhibits cytochrome $c$ translocation and caspase-3 activity. J Neurochem 85: 1026-1036, 2003.

37. Sudo $\mathrm{H}$ and Minami A: Regulation of apoptosis in nucleus pulposus cells by optimized exogenous Bcl-2 overexpression. J Orthop Res 28: 1608-1613, 2010.

38. Takei $\mathrm{N}$ and Endo $\mathrm{Y}: \mathrm{Ca}^{2+}$ ionophore-induced apoptosis on cultured embryonic rat cortical neurons. Brain Res 652: 65-70, 1994. 